\title{
Experiencing Cellularity
}

\author{
Review of: Cell Biology, by T.D. Pollard and W.C. Earnshaw, 2002; W.B. Saunders \\ (Philadelphia, PA); ISBN: 0721639976; http://www.us.elsevierhealth.com/SIMON/ \\ Pollard/
}

\author{
Reviewed by Ursula Goodenough, Washington University
}

Submitted April 2, 2003; Accepted April 2, 2003

Over the years, I have used various editions of Alberts and Lodish in teaching a one-semester upper-level undergraduate course in cell biology at Washington University. I understand that each of these books is in a new edition, neither of which I have examined. Therefore, in reviewing the new Pollard and Earnshaw textbook, Cell Biology, I will not be comparing it with other books, but rather describing, with great enthusiasm, my experience in using it to teach my course this semester.

The book represents a brilliant collaboration between the authors and an artist, Graham Johnson. Each core concept in each chapter is not only set forth in confident and uncluttered prose, but also illustrated in an elegant and dynamic original figure. Whenever possible, Johnson has drawn the accurate secondary structure of a given protein using PDB downloads, and all cellular components are drawn to scale, allowing an unprecedented opportunity to witness cellular pathways and their underlying mechanisms as they actually transpire. This yields continuous insights, as when a proteasome enters a process and we take in its enormous blimp-like size (Figure 20-9) or when we peer through a membrane bilayer and realize how skinny is the lone transmembrane helix of glycophorin (Figure 6-8). Figure 26-1, a gallery of 16 classes of receptors, transforms one's understanding of the diversity and the beauty of these proteins. Numerous light and electron micrographs, including vintage contributions by Don Fawcett, are also provided and carefully integrated into the text.

I realize that many instructors have learned to lecture using overheads of textbook figures, but textbook figures never before struck me as good teaching vehicles, so until this year, my lectures were accompanied by blackboard drawings that students dutifully transcribed into their notebooks and then attempted to relate to their textbook assignments. This semester, while I occasionally go to the board with a clarification or an update, I'm lecturing from the instructor-provided CD-ROM that contains a complete set of text figures and micrographs. This has proved to work remarkably well. I project a figure and slowly walk through it, delighting in the protein shapes and shape changes, explaining the concepts and the mechanisms in my own words, all the while knowing that the students will also be reading in their textbooks a lucid explana-

DOI: $10.1187 /$ cbe.03-04-0018

Corresponding reviewer. E-mail address: ursula@biodec.wustl. edu. tion that builds around the same figure. As a result, students effectively encounter the material twice, and while I was concerned that this might generate ennui, in fact their feedback has been enormously positive. Moreover, the median on the first hour exam was 10 points higher than in recent years, suggesting that they are also learning the material.

Some instructors may find offputting the fact that little coverage is given to how a given discovery in cell biology was made and by which scientists. The approach taken is more like Watson's classic Molecular Biology of the Gene (for those of you who go back that far), where the point is to convey how things work and not how such understandings were generated. This facilitates a narrative flow and a sense of being-inside-the-cell that, to my mind, can be all too readily disrupted by pausing to describe experimental trajectories. That being said, research strategies are described throughout the text, notably in Chapter 5 , and most of the figure legends offer technical details and full-titled references to recent research articles such that links to the bench can be easily tracked down.

Instructors may also be concerned that there are no chapterend summaries, review questions, glossaries, and the like. In fact, the "big picture" is consistently conveyed in chapter introductions, and a private Web site is being constructed, available by this summer, to provide ancillary support materials to instructors. Omitting these from the text means that there is less to lug around.

The book is organized into no less than 49 bite-size chapters, each with well-defined sections and careful but unobtrusive cross-referencing. Instructors can therefore readily pick and choose topics to emphasize or omit. For example, I designated as "optional reading" the chapters on gene expression and chromatin structure because these topics are covered in other courses in our curriculum, albeit I did so with regret since they are masterfully presented.

This book is really a tour de force. Somehow the authors are able to be concise without compromising readability or depth of explanation, and they make consistently interesting and often novel choices about what examples to present. The first chapters explain the principles of macromolecular structure and assembly with care and skill, giving strong emphasis to evolutionary thinking and to understandings gleaned from biophysics and from genetic analysis. These principles are then lifted up again and again in subsequent chapters so that macromolecular structure, assembly, and reaction kinetics become integral to everything that the cell is doing, which of course is the case. The chapters on membrane transport, 
for example, really deliver: enough detail is given to yield sophisticated understanding; the tedium that can plague the topic is avoided; and the unit concludes with fascinating accounts of synaptic transmission wherein the channels, carriers, and pumps we have been learning about all come together. The trafficking, signaling, matrix, motility, and cellcycle chapters are similarly first-rate, fresh in delivery and steeped in evolutionary perspective. Topics of medical rele- vance are lifted up but not given exaggerated importance, and cells of nervous, immune, and developmental systems are described in pathway-specific contexts rather than in artificial stand-alone chapters.

But nothing beats a look at the real thing. The book Web site (www.us.elsevierhealth.com/SIMON/Pollard/) offers an excellent introduction to the cellular world that Pollard, Earnshaw, and Johnson have so very skillfully crafted. 